\title{
Navetan olosuhteiden vaikutus lypsylehmien sorkkaterveyteen parsinavetoissa
}

\author{
Johanna Häggman $^{1)}$ ja Jarmo Juga ${ }^{1)}$ \\ ${ }^{1)}$ Maataloustieteiden laitos, PL 28,00014 Helsingin yliopisto, etunimi.sukunimi@helsinki.fi
}

\section{Tiivistelmä}

Hyvä sorkkaterveys on lypsylehmille tärkeää, koska useat sorkkasairaudet ovat kivuliaita ja aiheuttavat ontumista. Pihattojen yleistymisestä huolimatta vuonna 2010 Suomessa tuotantoseurannassa olevista lypsykarjatiloista 74,3\% oli parsinavetoita. Tässä tutkimuksessa tarkasteltiin parsinavetoiden erilaisten ympäristöolosuhteiden vaikutuksia suomalaisten ayrshire- ja holstein-rotuisten lypsylehmien sorkkaterveyteen. Tutkimuksessa käytettiin sorkkahoitajien vuosien 2005 ja 2009 välisenä aikana keräämää aineistoa, joka sisälsi tiedot 18038 ayrshire- ja holstein-rotuiselta lehmältä yhteensä 609 parsinavetasta. Aineisto sisälsi tiedot kahdeksasta eri sorkkasairaudesta. Tässä tutkimuksessa kaikki sorkkasairaudet yhdistettiin yhdeksi binomiaaliseksi (terve/sairas) sorkkaterveys muuttujaksi. Analyyseihin käytettiin R tilasto-ohjelmaa ja mallina logistista yleistettyä lineaarimallia, jossa oli satunnaistekijöinä sorkkahoitaja sekä karja (sorkkahoitajan sisällä). Saatujen tulosten perusteella rodulla oli suuri vaikutus sorkkaterveyteen. Holstein-rotuisista lehmistä $43,1 \%$ ja ayrshire-rotuisista lehmistä $32,4 \%$ oli yksi tai useampi sorkkasairaus. Sorkkasairaus riski kasvoi yhdessä poikimakertojen kanssa. Lehmät, joiden poikimakerta oli >3, olivat 5,19 kertaa suuremmassa riskissä sairastua sorkkasairauksiin verrattuna ensimmäistä kertaa poikiviin lehmiin. Erilainen väkirehuruokinta vaikutti sorkkasairauksien yleisyyteen. Tiloilla, joissa käytettiin tasaväkirehuruokintaa $(\mathrm{OR}=1,49, \mathrm{p}<0,001)$ oli enemmän sorkkasairauksia verrattuna tiloihin, jotka käyttivät tuotoksen mukaista ruokintaa. Lehmillä, joita pidettiin kuivalanta pitkäparsinavetoissa, oli 1,37 kertaa $(\mathrm{p}<0,001)$ suurempi riski sairastua sorkkasairauksiin verrattuna lehmiin, jotka olivat navetoissa joissa käytettiin lietelanta menetelmää. Kumimatot parsissa vähensivät sorkkasairausriskiä verrattuna betonialustaan ( $\mathrm{OR}=0,74, \mathrm{p}<0,001)$. Kesällä laitumella ja talvella ulkotarhassa olevilla lehmillä oli vähemmän sorkkasairauksia verrattuna aina sisällä pidettäviin lehmiin. Tulokset viittaavat siihen, että tuotoksenmukaista ruokintaa tulisi suosia ja kuivalanta pitkäparsinavetta lisäisi sorkkasairausriskiä. Tulosten perusteella lehmien olisi myös hyvä päästä ulos (laitumelle) ainakin kesäkaudella.

\section{Asiasanat}

Lypsylehmät, parsinavetta, sorkkaterveys, ympäristöolosuhteet 


\section{Johdanto}

Hyvä sorkkaterveys on lypsylehmille tärkeää hyvän tuotoksen, hyvän terveyden sekä yleisen hyvinvoinnin kannalta (Brand ym., 1996; Whay et al., 1998). Useat sorkkasairaudet ovat lypsylehmille kivuliaita, pitkäaikaisia ja ne aiheuttavat ontumista. Ontumiseen on useissa tutkimuksissa yhdistetty normaalista poikkeava makuukäyttäytyminen, pitkä toipumisaika ja hyvinvoinnin heikkeneminen (mm. Webster ym., 1995; Logue, 1996). Lisäksi sorkkasairauksien on todettu olevan kolmanneksi yleisin syy, utaretulehduksen ja hedelmättömyyden jälkeen, ennenaikaisiin poistoihin ja aiheuttavat tiloille myös huomattavia kustannuksia (Booth ym., 2004). Pihattonavetoiden yleistymisestä huolimatta vuonna 2010 Suomen tuotannonseurannassa olevista lypsykarjatiloista 74,3\% oli vielä parsinavetoita (Tietohaarukka, 2011). Useasta kirjallisuudesta löytyvät tutkimukset, jotka kuvaavat ympäristöolosuhteiden vaikutuksia sorkkaterveyteen, koskevat pihattonavetoita. Parsinavetoiden suuren lukumäärän takia on tärkeää tutkia ympäristöolosuhteiden vaikutusta myös suomalaisissa parsinavetoissa.

Tässä tutkimuksessa tarkasteltiin erilaisten navetan olosuhteiden vaikutuksia suomalaisten ayrshireja holstein-rotuisten lypsylehmien sorkkaterveyteen parsinavetoissa.

\section{Aineisto ja menetelmät}

Tutkimuksessa käytettiin sorkkahoitajien vuosien 2005 ja 2009 välisenä aikana keräämää aineistoa, joka sisälsi tiedot yhteensä 18038 ayrshire- ja holstein-rotuiselta lehmältä. Tutkimuksessa käytetty aineisto oli peräisin 609 parsinavetasta. Aineisto sisälsi tiedot kahdeksasta eri sorkkasairaudesta: vertymät anturassa, krooninen sorkkakuume, anturahaavauma, sorkkavälin ihotulehdus, sorkka-alueen ihotulehdus, kantasyöpymä, sorkkakiertymä ja valkoviivan repeämä. Aineistossa oli huomattavasti enemmän sorkkaterveyshavaintoja ayrshire-rotuisilta lehmiltä verrattuna holstein-rotuisiin lehmiin. Sorkkaterveyshavaintojen jakautuminen roduittain on esitetty Kuvassa 1.

Analyyseihin otettiin mukaan vain niiden päivien sorkkahoitohavainnot, jolloin oli hoidettu > 5 lehmää / karja / sorkkahoitopäivä. Näin ollen mukaan tulivat vain normaalit sorkkahoitokerrat ja pelkkien sairaustapauksien takia tehdyt sorkkahoidot saatiin karsittua aineistosta. Vain ne lehmät, jotka oli sorkkahoidettu yli 24 kk iässä, otettiin mukaan. Lisäksi ne havainnot, joiden osalta oli puuttuvia tietoja tärkeiden muuttujien osalta, poistettiin.

Analyyseihin käytettiin R tilasto-ohjelmaa (Venables ym., 2009) ja mallina logistista yleistettyä lineaarimallia. Mallin sisältämät kiinteät tekijät olivat: rotu, poikimakerta, vuosi-vuodenaika, navettatyyppi, ruokintatyyppi, makuualusta, kuivike ja ulkoilumahdollisuus. Lisäksi mallissa oli satunnaistekijöinä sorkkahoitaja ja karja (sorkkahoitajan sisällä).

Tässä tutkimuksessa haluttiin tutkia navetan olosuhteiden vaikutusta lypsylehmien yleiseen sorkkaterveyteen, minkä vuoksi kaikki sorkkasairaudet yhdistettiin yhdeksi binomiaaliseksi sorkkaterveys muuttujaksi, jolloin lehmä oli joko terve tai sillä oli yksi tai useampi sorkkasairaus.

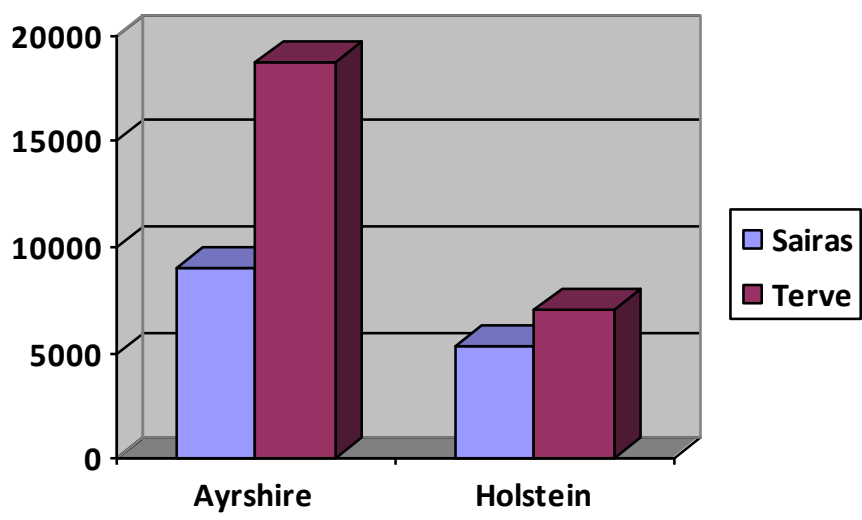

Kuva 1. Sorkkaterveyshavaintojen jakautuminen roduittain 


\section{Tulokset ja tulosten tarkastelu}

Saatujen tulosten perusteella rodulla oli suuri vaikutus sorkkaterveyteen. Holstein-rotuisista lehmistä $43,1 \%$ ja ayrshire-rotuisista lehmistä 32,4 \% oli yksi tai useampi sorkkasairaus.Lisäksi sorkkasairaus riski kasvoi yhdessä poikimakertojen kanssa. Lehmät, joiden poikimakerta oli >3, olivat 5,19 kertaa suuremmassa riskissä sairastua sorkkasairauksiin verrattuna ensimmäistä kertaa poikiviin lehmiin. Tulokset ovat samansuuntaisia kirjallisuuden kanssa. Punaisten rotujen on useissa tutkimuksissa todettu olevan parempia terveysominaisuuksien osalta verrattuna holstein-rotuun (mm. Kujala ym., 2010). Useissa sorkkaterveystutkimuksissa on myös todettu sorkkasairastumisriskin lisääntyvän yhdessä lehmän iän kanssa tai jos lehmällä on ollut ongelmia aiemmilla poikimakerroilla (Wells ym., 1993; Sogstad ym., 2005).

Tiloilla käytetty erilainen väkirehuruokinta vaikutti sorkkasairauksien yleisyyteen. Tiloilla, joilla käytettiin tasaväkirehuruokintaa $(\mathrm{OR}=1,49, \mathrm{p}<0,001)$ oli enemmän sorkkasairauksia verrattuna tiloihin, jotka käyttivät tuotoksen mukaista ruokintaa. Tässä tutkimuksessa ei huomioitu mm. väkirehun määrää, säilörehun laatua tai kuitupitoisuutta, joista kaikki ovat todennäköisempiä tekijöitä selittämään sorkkaterveyttä kuin ruokintatyyppi. Ruokintatyyppi kuvaakin luultavasti joitakin sen taustalla olevia muuttujia, jotka altistavat sorkkasairauksille. Tässä tutkimuksessa suurin osa tiloista käytti tuotoksenmukaista ruokintaa. Tasaväkirehuruokintaa käyttäviä tiloja oli noin $8 \%$ kaikista tiloista.

Parsinavettatyyppi / lannankäsittelytyyppi vaikutti sorkkasairauksien yleisyyteen. Lehmät, joita pidettiin kuivalanta pitkäparsinavetoissa, oli 1,37 kertaa ( $\mathrm{p}<0,001)$ suurempi riski sairastua sorkkasairauksiin verrattuna lehmiin, jotka olivat navetoissa, joissa käytettiin lietelanta menetelmää. Kuivalanta lyhytparsinavetoiden ja lietelanta menetelmää käyttävien navetoiden välillä ei löydetty tilastollisia eroja riskissä sairastua sorkkasairauksiin. Tuloksia selittää osittain se, että lietelanta menetelmää käyttävät navetat on helpompi pitää puhtaina verrattuna kuivalanta menetelmää käyttäviin navetoihin. Varsinkin pitkäparsinavetoissa lantaa kertyy parsiin enemmän ja siisteyteen vaikuttaa suurelta osin se miten usein parret puhdistetaan manuaalisesti. Pitkäparsinavetoissa parren siisteyteen vaikuttaa myös se, kuinka pitkiä aikoja parren etuosaa pidetään auki. Tutkimuksessa käytetyn aineiston osalta tällaisia tietoja ei ollut käytettävissä. Aineiston navetoista pitkäparsinavetoita oli noin $8 \%$ kaikista navetoista. Greenough (2007) totesi alustan kovuuden, karkeuden, liukkauden ja hygieenisyyden olevan tärkeitä sorkkaterveyteen vaikuttavia tekijöitä, ja totesi hyvän parsihygienian vähentävän tartunnallisia sorkkasairauksia.

Lehmillä, joilla oli kumimatot parsissa oli pienempi riski sairastua sorkkasairauteen verrattuna lehmiin, joilla ei ollut kumimattoa parsissa (betoninen parsi) $(\mathrm{OR}=0,74, \mathrm{p}<0,001)$. Myös muissa tutkimuksissa on saatu samanlaisia tuloksia (mm. Bergsten \& Frank., 1996; Vanegas ym., 2006). Erilaisten kuivikemateriaalien vaikutuksesta lypsylehmien sorkkaterveyteen ei löydetty tilastollisia eroja. Tässä tutkimuksessa ei tutkittu parren alustan materiaalin (matto/betoni) ja kuivikkeiden välisiä yhdysvaikutuksia. Suomessa kuivikkeita käytetään yleisesti melko vähäisiä määriä, joten kuivikkeiden käyttö ei juuri vaikuta parren kovuuteen. Näin ollen voisi olettaa parren pintamateriaalin vaikutuksen sorkkaterveyteen olevan suurempi kuin kuivikkeiden.

Niillä lehmillä, jotka pääsivät kesäisin laitumelle ja joilla oli talvisin ulkoilumahdollisuus (ulkotarha), oli vähemmän sorkkasairauksia verrattuna lehmiin, joita pidettiin ympärivuoden sisällä. Noin $10 \%$ lehmistä pääsi kesäisin laitumelle ja talvisin ulkotarhaan ja noin $8 \%$ lehmistä pidettiin ympärivuoden sisällä.

Sorkkahoitajan vaikutus oli suuri. Osa sorkkasairauksista on vaikeasti tunnistettavia, joten sorkkahoitajien välillä on voinut olla eroja sorkkasairauksien tunnistamisessa ja merkkaamisessa. Lisäksi eri sorkkahoitajien erilaiset sorkkahoitomenetelmät voivat osittain vaikuttaa sorkkahoitajien välisiin eroihin.

\section{Johtopäätökset}

Näiden tulosten perusteella voidaan suositella, että parsinavetoissa tulisi käyttää tuotoksenmukaista ruokintaa ja välttää kuivalanta pitkäparsinavetta yhdistelmää. Lehmien olisi myös hyvä päästä kesäisin laitumelle. Saatujen tulosten taustalla voi kuitenkin olla muita tekijöitä ns. taustamuuttujia, jotka todellisuudessa vaikuttavat sorkkaterveyteen. Näin ollen myöskään tässä tutkimuksessa saatujen tulosten perusteella ei voi tehdä täysin yksiselitteisiä johtopäätöksiä. Tutkimusta aiotaan jatkaa lisäämällä malliin myös navetan eri ympäristötekijöiden välisiä yhdysvaikutuksia. 


\section{Kirjallisuus}

Bergsten, C. \& Frank, B. 1996. Sole haemorrhages in tied primiparous cows as an indicator of periparturient laminitis: Effects of diet, flooring and season. Acta Veterinaria Scandinavica 37:383-394.

Brand, A., Noordhuizen, J.P.T.M. \& Schukken, Y.H. 1996. Herd health and 549 production management in dairy practice. Wageningen Pers, Kappale 7 osa 1.

Greenough, P.R. 1997. Lameness in Cattle, third ed. W. B. Saunders Company, Philadelphia, PA, p. 277.

Kujala, M., Dohoo, I.R. \& Soveri, T. 2010. White-line disease and haemorrhages in hooves of Finnish dairy cattle. Preventive Veterinary Medicine. 94:18-27.

Logue, D.N., Offer, J.E. \& Kempson, S.A. 1993. Lameness in dairy cattle. Irish Veterinary Journal. 46: 47-58. Sogstad, A.M., Fjeldaas, T., Osteras, O. \& Forshell, K.P. 2005. Prevalence of claw lesions in norwegian dairy cattle housed in tie stalls and free stalls. Preventive Veterinary Medicine. 70:191-209.

Tietohaarukka. 2011. Saatavilla: http://www.ruokatieto.fi

Vanegas, J., Overton, M., Berry, S.L. \& Sischo, W.M. 2006. Effect of rubber flooring on claw health in lactating dairy cows housed in free-stall barns. Journal of Dairy Science 89:4251-4258.

Venables, W. N., Smith, D. M. \& R Development Core Team. 2009. An Introduction to R. Saatavilla: http://www.r-project.org/

Webster, A.J.F. 1995. Animal Welfare: a Cool Eye towards Eden: a Constructive 910 Approach to the Man's Domination over Animals. Blackwell Science, Oxford, U K.

Wells, S.J., Trent, A.M., Marsh, W.E. \& Robinson, R.A. 1993. Prevalence and severity of lameness in lactating dairy cows in a sample of minnesota and wisconsin herds. Journal of American Veterinary Medicine Association. 202:78-82

Whay, H.R., Waterman, A.E., Webster, A.J. \& O'Brien, J.K. 1998. The influence of lesion type on the duration of hyperalgesia associated with hindlimb lameness in dairy cattle. Veterinary Journal 156:23-29. 